\title{
Recurring Patterns: Emily Brontë's Neurosis in Wuthering Heights
}

\author{
Moussa Pourya Asl \\ English Language and Literature Department \\ Azarbaijan Shahid Madani University of Tabriz \\ Tabriz, Iran \\ E-mail: ms_pourya@yahoo.com
}

Received: 02-11- 2013

doi:10.7575/aiac.ijels.v.2n.1p.46
Accepted: $18-12-2013$

Published: 31-01-2014

\begin{abstract}
Attempts to present a rational explanation of Emily Brontë's Wuthering Heights have been a growing concern since its publication in 1847. The abundant, yet incoherent, interpretations of Wuthering Heights, make the need for this research timely. This article focuses on ways to achieve a truer and more rational interpretation of the novel. The study indicates that in order to solve the enigma of the novel, the conscious and unconscious thoughts of the author, performing within the text, have to be discovered. The research approach adopted in this study is what is referred to as psychobiography or the Freudian psychoanalytic criticism. The findings of this research underline that Emily Brontë grew up in an oppressive milieu, and she compulsively created phantasy worlds within which she continuously repeated certain patterns. The main conclusion to be drawn from this article is that Emily Brontë was a neurotic person whose unconscious obsessions are projected in Wuthering Heights.
\end{abstract}

Key Words: Emily Brontë, Wuthering Heights, Neurosis, Obsession, Projection

\section{Introduction}

When we turn to the existing criticism of Emily Brontë's Wuthering Heights, we find the literature abundant and its coherence striking. Since its publication in 1847 , literary critics have taken widely different views about the novel's meaning. Unorthodox in its views, it has inspired remarkably diverse interpretations. Marxist critics like Terry Eagleton and Susan Meyer, feminist critics such as Sandra Gilbert, Susan Gubar and Margaret Homans and psychoanalysts like Bernard Paris and Marianne Thormählen have all attempted to present a single, unified and reasonable explanation and interpretation (Myths 105-7; "Reverse" 163-4; Madwoman 248-308; Women 104-162; Imagined 240-61; "Lunatic" 18397). While all of these tandpoints are useful and valid, it seems that Charlotte was right in declaring that critics have ceased to do Wuthering Heights justice and the difficulty of finding a true interpretation of the novel is yet to be overcome (Charlotte, 1850a, p. 363).

Critics like Margaret Homans, Joseph Hillis Miller and Stevie Davies have introduced a number of reasons for the reader's difficulty "to reach the inside of the inside [of the novel] where a full retrospective explanation of all the enigmatic details will be possible" (Miller, 1991, p. 362). Homans, for instance, asserts that part of this difficulty is due to Emily Brontë's belief that language cannot convey reality. Therefore, the novel withholds any certain knowledge and accordingly "obstructs the readers' access" to the latent meaning behind the vessels created by it (Homans, 2006, p. 281). In a similar way, Miller claims that the reader's difficulty in interpreting Wuthering Heights stems from the novel's own enigmatic structure. He argues that the novel, with its intricate structure of flashbacks, time shifts, multiple perspectives, and narrators within narrators leaves the reader wandering in search of a deeper perspective (Miller, 1991, pp. 165-6). Akin to what Homans and Miller argue, Davies points to Emily Brontë's conception of reality as "intricately relativistic", concluding that Emily Brontë 's framed and fragmented presentation of reality mocks the reader in his/her attempt to come to any conclusions (1983, pp. 97-8).

In this article, I employ Freudian psychoanalysis to delve into the private motives behind Emily Brontë's public act of writing. By gaining such an in-depth understanding of the author, we would be able to better interpret her novel. The questions I seek to answer in this section include: how is the Freudian assumption that all artists, including authors, are neurotic applicable to Emily Brontë, and what are the latent and unconscious detriments of her psyche that are projected onto the manifest elements of the novel?

Before turing to the discussion section, a couple of important issues need to be elucidated: first, the significance of and the need for conductucing research on an outdated novel (written in 1847) in the current century, and second, explanation of the reasons why Freud rather than Lacan's theories have been incorporated into this study. Despite its initial unfavourable public reception, Mrs Humphry Ward was right in claiming that Emily Brontë writes "for all time" (Winnifrith, "Rise and Fall" 18). In recent years, Emily Brontë's reputation has dramatically risen and the public has shown an enthusiastic interest in reading Wuthering Heights. A powerful instance of preference for Emily Brontë over other novelists can be found in an important survey accomplished in 2007 by The Guardian to find Wuthering Heights as the greatest love story of all time. According to Martin Wainwright, Wuthering Heights hit the heights and took the 
first place, seeing off beating authors like Shakespeare, Jane Austen, Barbara Cartland and her own sister Charlotte Brontë (par. 1).

As for justification and rationalization of Freud over other theorists, I selected the Freudian approach due to some "remarkable shifts in opinion towards" him that has occurred in the 1980s and 1990s (Horracks 20). The latest scholarly studies on Freud have suggested that "the anti-Freudian moment may already have begun to pass" and have made Freud "the indispensable starting point for any serious student of psychoanalysis or psychotherapy, surely, and for (at the least) many serious studentsof psychology, psychiatry, and the other behavioral sciences" (4).

\section{Discussion: From Repression to Obsession}

\subsection{Theoretical Background}

In the first place, it is appropriate to note that central to Freudian psychoanalytic criticism is Freud's assumption that all artists, including authors, are neurotic. To him a work of literature was the external expression of the author's unconscious mind and the chief motivation for writing any text was to satisfy some secret impulses, some repressed wishes that might have developed during the creative writer's infancy and were instantly suppressed and dumped in the unconscious. Therefore, to Freud, neurosis is rooted in the individual's "repressed memories" that are kept at a distance from the conscious, i.e. in the unconscious (1915, p. 2978).

Freud identified three chief types of neurosis as obsessive-compulsive, hysterical and phobic. He defined obsessivecompulsive disorder as an anxiety disorder characterized by intrusive thoughts (obsessions) and by repetitive behaviors (compulsions) intended for reducing anxiety. According to him the neurotic individual relies on compulsions as an escape from his/her obsessive thoughts, though with an awareness that the relief is only temporary (1907, p.1901). Freud declared, "any activities whatever may become obsessive actions in the wider sense of the term if they are elaborated by small additions or given a rhythmic character by means of pauses and repetitions" (p.1902).

Freud claims that one way in which we cope with neurosis or with the wishes that we cannot fulfill is by sublimating them; i.e. by switching and harnessing them towards a more socially valued goal like literature. In other words, the unconscious is always trying to avoid repression and thus bypass the symbolic order. This revelation is done through parapraxes, dreams and imaginative activities like literature, art and phantasies in which the unconscious desires are fulfilled.

Freud argues that the creative writer, like a child at play, creates a world of phantasy in which he rearranges things as he pleases (1908, p. 1921). This world of phantasy is the fulfillment of an unconscious wish which comes to expression in a disguised form, undergoing the unconscious processes of distortion, displacement and condensation which present such repressed impulses in the form of images and symbols. Freud calls such images and symbols the "manifest content" which point beyond themselves but reveal "sources of desire coming from deep within us" (Lear, 2005, p. 91). However, the author's hidden motivation and the work of art's hidden meaning is yet to be uncovered through a systematic method of interpretation. Freud lays down a major principle of such an interpretation and declares "the interpretation of a dream must take the context of the dreamer's life into account" (pp. 91-92).

Freud states that we should "look for the first traces of imaginative activity as early as in childhood" (1908, p. 1921). A child, like a creative writer, creates a world, "re-arranges things as he pleases" and having taken it very seriously cathects large amounts of emotion on it. The child and the writer distinguish the world of phantasyfrom reality. They realize that "many things which, if they were real, could give no enjoyment, can do so in the play of phantasy" (p. 1922). Therfore, the motives of phantasies, according to Freud, lie in the fact that "...a happy person never phantasies, only an unsatisfied one [does]. The motive forces of phantasies are unsatisfied wishes, and every single phantasy is the fulfillment of a wish, a correction of unsatisfying reality" (p. 1924).

Finally, it is easy to conclude that in Freudian psychoanalysis, the creative writer is regarded as a neurotic individual whose unresolved mental conflicts are at work behind the manifest content of the work of art. As Freud argues, the creative writer suffers from particular obsessive thoughts, which are rooted in his/her Oedipal stages of sexual development, and which he/she projects on his/her phantasy worlds in a distorted form, to mitigate the anxiety emanated from his/her obsessive impulses . Freud asserts that a systematic method of interpretation - that is by taking the author's life into account, by scrutinizing the manifest content of the work of art, and finally by studying the repeated patterns, as a key indication of obsessive-compulsive disorder - will lead the reader to a better understanding of the work of art (Bressler, 2007, pp. 156-7).

\subsection{Repressive Milieu}

The application of Freudian perspectives to Emily Brontë's personal life and novel reveals that she suffered from neurosis, displayed in the form of physical and psychological abnormalities. She became neurotic since her primary instinctual impulses encountered with severe prohibition and suppression that was imposed on by her father, school and society.

Emily Brontë grew up in a religious family and society. Her father's foremost influence on Emily was her eventual development of an overactive superego. As a family oppressor, Patrick subscribed to the "orthodox view that female nature was inherently domestic and that female vocation was ideally located within the home" and that "women should learn in silence, with all subjection to male authority" (Lamonica, 2003, p. 20). He also firmly advocated the Victorian idea that childhood is a period during which the characters and habits of the future men are formed (p. 15). Therefore, he obliged his children, Emily among them, to repel and repress most of their primary desires and impulses in order to 
fit into the society by acting in a socially appropriate manner. Viewed from Freudian psychoanalysis, this kind of constant surveillance and correction rendered Emily, as an individual, to realize that acting on some desires may bring anxiety, leading to a repression of the related desire.

The traumatic education at Clergy Daughter's school which was for the education of poor clergymen's daughters further reinforced Emily Brontë's hyperactive superego. The school's "great object", according to its advertisement, "was the intellectual and religious improvement of its pupils with an extreme obsession with early death of eternal punishment (pp. 15-23). The effects of schooldays at Cowan Bridge on the Brontë girls were dramatic. It "was run on spartan lines, designed to encourage resignation and humility" due to the fact that the future prospects in life of the girl pupils, who belonged to an impoverished class, were unpromising. Eventually, thedeplorable conditions of the school like the "severity of its routine" andmalnutrition and ill-health led to death of Emily's two young sisters Elizabeth and Maria in 1825, leaving Emily feel forlorn and dejected (Brier, 1978, p. 237).

Victorian society's rigid definition of gender roles, which was used "to oppress females of all ages and elevate males to positions of dominance in all spheres of human activity", additionally cultivated Emily Brontë's internal voicesuperego (Tyson, 2006, p. 27). It was a society that endorsed imposition of limits on the self, punishing transgressions, internalizing restraints, developing conscience, confining women in the home and segregating them from public spheres of influence, and finally implanting principles of subordination according to a hierarchy of power relations - children submit to parents, wives to husbands (Lamonica, 2003, pp. 1035).

Concluding from the points put forward above, it is clear that Emily Brontë grew up in a rigorously oppressive milieu, being subjected to extreme and unrealistic self-criticism. She was afraid of and anxious about the ever-possible threat of wrongdoing and deviation. The anxiety, arisen within her, produced repression, and consequently, her superego began suppressing the desires and instincts forbidden by society and thrusting them back into the unconscious. These buried wishes, in Freudian psychoanalysis, seek expression and often find their way in neurotic symptoms like obsession, phobia and hysteria.

\subsection{Recurring Patterns}

Freud's concept of the neurotic symptom of obsession could be applied to Emily Brontë in the sense that she was obsessed with certain thoughts that recurred and persisted despite her unconscious efforts to block them. Rejection of father figure and psychoanalytic love of mother form the matrix of her obsessions. Eventually, she found an unconscious outlet for partial satisfaction with her frustrated impulses in her phantasies. As an obsessed individual, Emily Brontë had a habit of creating phantasy worlds within which she repeated certain patterns. Phantasizing and writing became a compulsive ritual for her to mitigate the anxiety that stemed from her particular obsessive thoughts. She relied on these compulsions - repeated phantasy worlds - as an escape from her obsessive thoughts. In this world of escape and through sublimation, she attempted to neutralize the intrusive thoughts and impulses with some other thoughts like the repeated patterns of orphaned characters, infanticide and sadism and cycle of names, to name a few.

Emily Brontë's early instances of phantasizing could be found in her participation in Glass Town Saga, when she was only eight. There is almost certainly significance in the fact that Emily Brontë, like her brother and sisters, had an interest in the supernatural, imagining herself as a genii with fantastic powers, who not only was able to shape the world entirely to her own desires but also had the power to bring the dead back to life. This delight in having a sense of power and freedom emerges repetitively in almost all her later phantasies (Chitham, 2001, p. 80).

The kingdom of Gondal was a "female governed fantasy realm" that advocated the ascendancy of the psychological subject (Krueger, 2003, 41). The prose literature of Gondal does not survive. What we have is 200-odd poems of Emily Brontë that repeatedly display the unconscious projection of her repressed desires and are "the culmination of an experience that contains within it a reaction to the universe (Gezari, 2007, p. 2).

Gondal characters, on top of them Augusta, reveal Emily Brontë's inferiority complex and power envy when they apostrophize liberty and display their will to power. Augusta, "an untrammeled egotist, a female Byronic hero", pursues her ownpassions and lives in an almost entirely amoral universe. She directly speaks for Emily when she ruthlessly demands for power, and in this regard, prefigures Catherine Earnshaw (Gordon, 1989, p. 184).

It seems that a quest for power, liberty, revenge and passion are the underlying themes that persistently recur within Emily Brontë's all phantasy worlds. Liberty, as Charlotte declares, was the breath of Emily's nostrils and throughout her life she was seeking a world to demolish hierarchies of power relations and to promote an equality for both genders (Winifrith, 1989, pp. 96-7).

Emily Brontë's intrusive thoughts also reappear in her novel. Wuthering Heights is "a radical reworking of the spiritual experience that had first found expression in the poems" (qtd. in O'Neil, 1995, p. 8). It seems that Emily was preoccupied with certain thoughts and she indulged in phantasy, to the exclusion of reality. What she gained from phasntasizing, I stress, was a temporary relief from the unbearable constraints and oppressions of the reality, since, as it is suggested by Freudian psychoanalysis, "many things, which, if they were real, could give no enjoyment, can do so in the play of phantasy, and many excitements which, in themselves, are actually distressing, can become a source of pleasure" (Freud, 1908, p. 1923).

Wuthering Heights is fraught with so many repetitions that it is called "a book of repeating cycles and recurring patterns" (Woodford, 2006, p. 79). Considering the concept of repetition in Wuthering Heights, one is struck by numerous forms of repeated patterns: violent men, cycle of names, orphaned and abandoned children, a system of 
masters and servants, reincarnation of characters, infanticide and sadism and brother/sister selves. Beneath all these repetitions as the manifest contentunderlies a key fact that Emily Brontë implemented them compulsively in response to certain obsessions.

One of the key repetitions of the novel is a series of tyrannical men who rule Wuthering Heights-Mr. Earnshaw, Hindley and Heathcliff. At first, Mr. Earnshaw reigns Wuthering Heights with violence and curses. Then the ruthless Hindley becomes the successor of Mr. Earnshaw. And finally, it is through the fiendish Heathcliff that the sequence of violent men comes to an end (p. 80).

Another repetition in the novel is the cycle of names of Catherine, Earnshaw, Heathcliff and Linton. The names reappear in the three generations that the novel tells a story of. Lockwood finds these names repeated in various ways in a book as well as a window ledge at the Heights. Catherine Earnshaw, for instance, becomes Catherine Linton through her marriage with Edgar. Then she gives birth to another Catherine, i.e. Catherine Linton, who comes to the world only hours before her mother, Catherine Earnshaw, leaves it. The second Catherine first marries Linton Heathcliff, and becomes Catherine Heathcliff. After that, at the end of the book, she gets engaged to Hareton Earnshaw and becomes another Catherine Earnshaw (p. 79).

Orphaned and abandoned characters is yet another recurring pattern that fills the Novel and reveals Emily Brontë's obsession with the fear of loss she had experienced in her childhood. Indeed, "death haunts the novel as it so terribly haunted Brontë family" (Polhemus, 1990, p. 99). Therefore, many of the characters-including Heathcliff, Catherine, Linton, Hareton, Isabella and Cathy — share with her thetraumatic experience of their mother's early death.

In addition to these recurring patterns, a system of masters and servants marks the novel, too. Most of the characters of the novel seem beset by a "master complex", having a strong desire to exercise authority over other people (Tytler, 2008, p. 47). Hindley demands everyone to obey him "You forget you have a master here"; Heathcliff envisages his eventual power over the two places "I want the triumph of seeing my descendant fairly lord of their estates"; Catherine who likes, exceedingly, to act the little mistress, manifests this complex in childhood, and when she grows up, she also develops "notions of superiority and self-importance" that she cannot imagine not to be the "central concern in everyone else's life" (Federico, 2006, p. 78).

In addition to these repeated cycles is the repetition of characters, like Cathy and Hareton, in the form of reproductions and reincarnations. Cathy, for instance, is in many ways a reembodiment of her mother Catherine, "the daughter turned out a second edition of the mother", sharing her mother's rebelliousness and scorn for those who interfere with her plans(ch.xiv, p. 121). Even young Cathy's marriage is a "revision of her mother's unsuccessful marriage to Edgar Linton"(Federico, 2006, p.76). Hareton is also an imitation of his father. In other words, he is a gentler version of his oppressing and foster father, Heathcliff, who claims "Hareton seemed a personification of my youth" (ch. xxxiii, p. 247).

The sequence of repeated patterns continues with the recurrent concept of infanticide and sadism. The children in Wuthering Heights are constantly struggling for their survival. The adults, on the other hand, are obsessed with a desire to kill or maim the children. Indeed, Emily Brontë's preoccupation with this concept leads Wade Thompson to claim that "the world of W. H. is a world of sadism, violence and wanton cruelty, wherein children - without the protection of their mothers - have to fight for very life against adults who show no tenderness, love or mercy" (Thompson, 1963, p. 97). First, we have the children's traumatic experience of their mother's early death. Then, in the absence of their mother, they have to struggle against the cruelty of adults. The children live in continuing danger: for instance, Heathcliff encounters the Earnshaws' malice when he is introduced to the family; Hareton survives Hindley, Heathcliff and Nelly Dean's brutalities; and Linton Heathcliff is gradually tormented to death by his father Heathcliff.

The theme of sadism is also portrayed symbolically in the killing of helpless and delicate animals. Hareton hangs "a litter of puppies from a chair-back". Heathcliff hangs Isabella's "little pet springer". Catherine recalls Heathcliff set a trap over a lapwig's nest. Linton, as sport, tortures the cats to death and Lockwood finds "a heap of dead rabbits" in the Heathcliff household (p. 96).

Wuthering Heights is replete with the metaphor of "fusing and diffusing brother/-sister selves", too. There are about six pairs of brother/sister relations including Hindley/Catherine, Edgar/Isabella, Catherine/Heathcliff, Nelly/Hindley, Linton/Cathy and finally Hareton/Cathy (Knoepflmacher, 1989, pp. 67-8). Though some of these pairs, at first glance, may seem untrue, they are justifiable by the late eighteenth century definition of family, according to which "the term family [...] was used in England [...] to designate resident kinsfolk as well as domestic servants, insofar asboth were subject to the same patriarchal head" (Lamonica, 2003, pp. 10-11). Each of these groups falls into the process of "fusion, separation, and reintegration", the last phase of which may be interpreted as regression, which is an unconscious yearning to be reintegrated with the mother figure.

In summary, the world of Wuthering Heights is a world of repeating cycles and recurring patterns: violent men, cycle of names, orphaned and abandoned children, a system of masters and servants, reincarnation of characters, infanticide and sadism and brother/sister selves. These are only some of the repeated patterns that form the basis of the novel. In like manner, these patterns construct the manifest content of Emily Brontë's other phantasy worlds - Glass Town saga, Gondal saga, and Poems - as well. In Freudian psychoanalysis, these repetitions point to the one crucial fact that the creative writer, in our case Emily Brontë, suffers from obsessive-compulsive disorder.

To round up the discussion, it is concluded that the obsessive-compulsive disorder is a specific form of neurosis that aims at reducing the anxiety that stems from particular obsessive thoughts and the primary reason that lies at the bottom 
of the disorder is the repression of an instinctual impulse, which in case of Emily Brontë is the Oedipus complex. To cope with neurosis, Emily Brontë, as a creative writer, unconsciously constructs a world of phantasy in accordance with the repressed impulses.

\section{Conclusion}

In the century since its publication, Wuthering Heights has been the subject of an extensive and often contradictory range of interpretations and criticisms. To attain a more genuine perception of the novel, in this research, the Freudian postulations on the essence and implications of works of art have been employed. To Freud, the creative writer is a neurotic individual and the work of art is the external expression of the artist's unconscious mind.

An exploration into the personal life of Emily Brontë and her Wuthering Heights reveals that Emily Brontë grew up as a neurotic person to create phantasy worlds within which she would be able to gratify her secret wishes. Her neurosis was originally triggered by the severe prohibition and suppression that she had undergone in her childhood. Her oppressive father, the harsh regime of Clergy Daughter's School and the Victorian society's rigid definition of gender roles, which endorsed oppression of females in all ages, created a rigorously oppressive milieu that ultimately led Emily Brontë to develop an overactive superego to suppress the desires forbidden by society. These repressed impulses, according to Freud, find their path to expression in neurotic symptoms like obsession, phobia and hysteria.

Emily Brontë obsessively created phantasy worlds - Glass Town Saga, Kingdom of Angria, Kingdom of Gondal, Gondal poems - within which she found an unconscious outlet for the partial gratification of her repressed wishes. In response to certain obsessions, she compulsively filled these worlds with various forms of repeated patterns. In Wuthering Heights, for instance, she repeated certain patterns like violent men; cycle of names; orphaned and abandoned children; a system of masters and servants; reincarnation of characters; infanticide and sadism and brother/sister selves. The repetitions confirmed that Emily Brontë suffered from obsessive compulsive disorder which is a specific form of neurosis.

Lastly, the principle recommendation to be made is an in-depth study of Emily Brontë's other phantasy worlds. Admittedly, there are other areas of study that could benefit prospective researchers. For example, further research could focus on areas that were touched on only briefly in this study, such as Emily Brontë's poems. In the context of Freudian psychoanalysis, which deals with literary works as the outward manifestation of the artist's suppressed wishes, the poems will evidence enough proofs of Emily Brontë's obsessive thoughts in particular, and the neurotic state of the creative writer in general.

\section{References}

Bressler, Charles E. (2007). Literary Criticism: An Introduction to Theory and Practice. $4^{\text {th }}$ ed. New Jersey: Pearson, Brier, Peter A. (1978). Introduction to Emily Brontë's Wuthering Heights. In N. Magill, Frank (Ed.) Vol. 4 of 1300 Critical Evaluation of Selected Novels and Plays. Salem Press.

Brontë, Charlotte. (1850a).Biographical Notice of Ellis and Acton Bell. In Jack, Ian and Patsy Stoneman (Eds.) Wuthering Heights Oxford World's Classics. Oxford University Press.

Brontë, Charlotte. (1850b). Editor's Preface to the New Edition of Wuthering Heights. In Jack, Ian and Patsy Stoneman (Eds.) Wuthering Heights Oxford World's Classics. Oxford University Press.

Chitham, Edward. (2001). The Birth of Wuthering Heights: Emily Brontë at Work. Hampshire:Palgrave.

Davies, Stevie. ((1983). Structure and Point of View in the Novel. Harold, Blooms (Ed.). The Brontës, Bloom's Major Novelists, ed. Harold Bloom. U.S.A: Chelsea House Publishers.

Dunn, Richard J. ed. (2003) A Norton Critical Edition: Emily Brontë Wuthering Heights. $4^{\text {th }}$ ed. New York: W.W. Norton.

Eagleton, Terry. (2005). Myths of Power: A Marxist Study of the Brontës. Palgrave Macmillan, 2005

Federico, Annette R. (2006). The Waif at the Window: Emily Brontë's Feminine 'Bildungsroman'. eNotes. Gale.

Freud, Sigmund.( 1907a). "Obsessive Actions and Religious Practices." . The Standard Edition of the Complete Psychological Works of Sigmund Freud. Trans. James Strachey. 24 vols. London: Hogarth, 1953-74.

Freud, Sigmund. (1908b). Creative Writers and Day-dreaming. The Standard Edition of the Complete Psychological Works of Sigmund Freud.

Freud, Sigmund. (1915c). Repression. The Standard Edition of the Complete Psychological Works of Sigmund Freud. Gezari, Janet. (2007). Last Things, Emily Brontë's Poems. New York: Oxford UP.

Gilbert, Sandra M. and Susan Gubar. (2000). The Madwoman in the Attic: the Woman Writer and the NineteenthCentury Literary Imagination. Yale University Press.

Gordon, Felicia. (1989). A Preface to the Brontës. New York: Longman.

Homans, Margaret. (1987a). Women Writers and Poetic Identity: Dorothy Wordsworth, Emily Brontë, and Emily Dickinson. Princeton University Press. 
Homans, Margaret. (2006b). The Brontës. Vol. 1 of The Oxford Encyclopedia of British Literature. Oxford University Press.

Horrocks, Roger.(2001) Freud Revisited: Psychoanalytic Themes in the Postmodern Age. New York: Palgrave.

Knoepflmacher, U. C. (1989). The Creation of Heathcliff. In Bloom, Harold (Ed.). Emily Brontë's Wuthering Heights Bloom's Notes. U.S.A: Chelsea House Publishers.

Krueger, Christine, et al. (Eds.). (2003). Vol. 1 of Encyclopedia of British Writers, $19^{\text {th }}$ Century. 2 vols. New York: Book Builders LLC.

Lamonica, Drew. (2003). "We Are Three Sisters": Self and Family in the Writing of the Brontës. London :University of Missouri Press.

Lear, Jonathan. (2005). Freud. USA: Routledge.

Meyer, Susan. (1996). "Your Father Was Emperor of China, and Your Mother an Indian Queen: Reverse Imperialism in Wuthering Heights". Imperialism at Home: Race and Victorian Women's Fiction. Cornell University.

Miller, J.Hillis. (1991). The Disappearance of God: Five Nineteenth Century Writers. U.S.A: Harvard University Press.

O'Neill, Judith, (Ed.). (1995). Critics on Charlotte and Emily Brontë: Readings in Literary Criticism. New Delhi: Universal Book Stall.

Paris, Bernard J. (1997). Imagined Human Beings: A Psychological Approach to Character and Conflict in Literature. New York: New York University Press.

Polhemus, Robert M. (1990). Love and Death in the Novel. In Bloom, Harold. (Ed.). The Brontës, Bloom's Major Novelists, ed. Harold. U.S.A: Chelsea House Publishers.

Thompson, Wade. (1963). Infanticide and Sadism In Wuthering Heights. In O'Neill, Judith (Ed.). Critics on Carlotte and Emily Brontë. New Delhi: Universal Book Stall.

Thormählen, Marianne. (1997). "The Lunatic and the Devil's Disciple: The 'Lovers' in Wuthering Heights" Bloom's Guides: Emily Brontë's Wuthering Heights. Ed. Harold Bloom. New York:Bloom's Literary Criticism, 2008.

Tyson, Lois. (2006). Psychoanalytic Criticism. Critical Theory Today. $2^{\text {nd }}$ ed. New York, Routledge.

Tytler, Graeme. (March 2008). Masters and Servants in Wuthering Heights. Vol. 33 of Brontë Studies.

Wainwright, Martin. (2007). "Emily Brontë hits the Heights in Poll to Find Greatest Love Story." The Guardian. 10 August 2007. <http://www.guardian.co.uk/uk/2007/aug/10/books.booksnews>

Winnifrith, Tom. (1989a). Emily Brontë. In Todd, Jannet. (Ed.). Dictionary of British Woman Writers. London:

Routledge.

Winnifrith, Tom. (1996b). Charlotte and Emily Brontë: A Study in the Rise and Fall of Literary Reputations. The Yearbook of English Studies, Vol. 26, Strategies of Reading: Dickens and after Special Number. Pp. 14-24. JSTOR 3 August 2007.<http://www.jstor.org/stable/03062473>

Woodford, Donna C. (2006). Repeating Cycles and Recurring Patterns in WutheringHeights. eNotes. Gale. 